\title{
Accompaniment on Application of Concentrates as Cattle Feed for Palm-Oil Plantation Farmers
}

\author{
Endang Baliarti ${ }^{1 *}$, Hamdani Maulana ${ }^{1}$, Nono Ngadiyono $^{1}$, I Gede Suparta Budisatria ${ }^{1}$, Panjono ${ }^{1}$, Tri \\ Satya Mastuti Widi ${ }^{1}$, M Danang Eko Yulianto ${ }^{1}$, Bayu Andri Atmoko ${ }^{2}$ \\ ${ }^{1}$ Department of Animal Production, Faculty of Animal Science, Universitas Gadjah Mada, Depok, Sleman, D.I. \\ Yogyakarta \\ ${ }^{2}$ Doctoral student at Faculty of Animal Science, Universitas Gadjah Mada, Depok, Sleman, D.I. Yogyakarta
}

Submisi: 24 January 2020; Revisi: 25 May 2020; Penerimaan: 25 June 2020

Keywords:
community
services
activity
feed technology
Palm oil-cattle
Integration
system

\begin{abstract}
Abstrak The activity aims to trial and applies the result of the study of the palm oil plantation-cattle integration system, especially in feed technology, and increase the knowledge and ability of cattle maintenance for Karya Bersama farmers groups. Karya Bersama is one of the farmers' groups that develop palm oil plantation-cattle integration. The activities are carried out from July to November 2017 at the Sawit-Sapi Center, and the Karya Bersama Farmers Group located in Rokan Hulu District, Riau. The activity began with the socialization of the ingredients, function, benefits of concentrate feed, and concentrate feed production process at Sawit-Sapi Center. The activity continued with the application trial of concentrate feed for cattle belonging to farmers and accompaniment for two months. The results showed that the concentrate feed containing $55-60 \%$ of palm kernel oil with $17,42 \%$ protein content has excellent palatability. Each cattle is given $2 \mathrm{~kg} /$ day, always consumed. The activities received a very positive response, so we hope this activity would increase the farmers' enthusiasm to improve their cow performance.
\end{abstract}

\section{INTRODUCTION}

Based on Regulation of The Minister of Agriculture No. 105/Permentan/PD.300/8/2014 that integration of the oil palm-cattle business is the integration of plantation business with beef cattle cultivation on oil palm plantation land by utilizing by-products of oil palm plantation business (palm kernel cake, palm mud and palm fronds) and cattle manure as fertilizer, bio urine, and biogas (Kementrian Pertanian, 2014). The pattern of palm-oil-cattle integration carried out by plasma farmers in Siak Regency, Riau utilizes forage in the area of oil palm plantations and utilizing livestock manure as fertilizer for oil palm plants. So the farmers can save the cost of animal feed, fertilizer, and weeding in oil palm plantation. This condition supported the replanting of oil palm plants, which generally takes five years so that the cattle become an alternative source of income for farmers during replanting (Baliarti et al., 2016).

Rokan Hulu District is one of the regions of Riau Province with the highest commodity of oil palm plantation and is the center for the development of cattle breeding along with Kuantan Singingi, Indragiri Hulu, Siak and Pelalawan District. Riau Province has 3,46 million hectares of oil palm plantations. In Rokan Hulu District, half of the area $\left(8513,7 \mathrm{~km}^{2}\right)$ used for oil palm plantations, and $56 \%$ managed by smallholder farmers (Direktorat Jenderal Perkebunan, 2015). With the area of oil palm plantations, Rokan Hulu District is feasible and has the potential to develop the palm-oil plantationcattle integration system. The action was stated through Regent Regulation Number 45 in 2012, through the gradual assistance of cattle breed annually to smallholder farmers who are members of the

ISSN 2460-9447 (print), ISSN 2541-5883 (online)

${ }^{*}$ Corresponding author : Endang Baliarti

${ }^{1}$ Departement of Animal Production, Faculty of Animal Science, Universitas Gadjah Mada, Jl. Fauna No.3, Kampus UGM, Bulaksumur, Depok, Sleman, 55281, D.I. Yogyakarta

Email: bali_arti@ugm.ac.id 
Community Breeders' Centers or Sentra Peternakan Rakyat (SPR) (Yatma, 2017).

One of the recipients of cattle grants and assistance from the Government of Rokan Hulu District is the Karya Bersama farmers group, which included in the Maju Barokah Community Breeders' Centers in Karya Mulya Village, Rokan Hulu District, Riau Province. The majority of the farmers' group members are smallholder oil palm farmers either as business partners of an oil-palm plantation company or as the landowners. Cattle were maintained an integrated with oil palm plantations. Karya Bersama farmers group started up in 2010 and in 2011 received Bali Cows grant and assistance from the Rokan Hulu District Plantation and Animal Husbandry Agency (personal communication).

The main problem of Karya Bersama farmers is the lack of motivation of farmers to make the livestock sector a source of income and livelihood in addition to the oil-palm plantation sector. The majority of farmers group members are transmigrant communities who receive assistance from the 2 ha oil-palm plantation and have part-time rice farming in the area around their homes. The motivation for livestock ownership still limited to savings and insurance. The farmers have not yet thought to maximize livestock productivity and commercially available by-products. Karya Bersama farmers group has also designated as an animal feed center in the form of forages and rice straw from paddy fields. The farmers prefer to provide forage feed rather than buying concentrate feed for their cattle because of the use of concentrate considered to have no significant impact and, in terms of price, expensive. The farmers also still do not fully understand the concentrate feed and the function of each ingredient. Limited farmers' knowledge about making and preparing feed rations is why the farmers' group does not yet produce the concentrate feeds. So the feedstuff aid from the Rokan Hulu District Plantation and Animal Husbandry Agency only piles up in the barn. The feedstuff has the quality decreased, contaminated, and infected by fleas in the barn.

Similar to the condition, Baliarti et al. (2017) stated that the beef cattle breeding system in the oil palm plantation area carried out by plasma farmers in Siak District, Riau is still traditional. The average number of ownership is three heads/farmers, the purpose of maintenance livestock as a side business of farming oil palm plantation and feeding only with forage without the addition of concentrate. Therefore, it needs assistance and application of concentrate feed to increase livestock productivity, so that later it can be used to increase the income of these farmers. Low livestock productivity, especially in the cows to produce a calf, (low calf crop) can reduce farming motivation. Farmers in the Karya Bersama farmers group consider cattle to have a crucial function in the household as invaluable savings for benefits when they encounter contingent expenses. An alternative source of income from the cattle farming enterprise is to utilize its manure to be processed into organic fertilizer so that it is economically valuable (Atmoko et al., 2019). In cattle farming with an integrated oil palm plantation system, it will be very beneficial if the manure used for the palm oil plants. The integration of livestock and oil palm also influences oil palm production. Yields of fresh fruit bunches reported to have increased by 3.5 tons/ ha/ year or by around 30\% compared to without integration and farmers income has increased by $50 \%$ (Gunawan \& Talib, 2014),

One of the appropriate technology programs in the palm-oil-cattle integration system is the feed production based by-product of the oil-palm plantation. Baliarti et al. (2015) report on the Sawit-Sapi Center program at PT. Perkebunan Nusantara V, Sei Rokan Riau, has produced concentrate feed by utilizing palm kernel cake (oil-palm by-product) with 50\% of the total ration formulation. Concentrate feed proved to be palatable to cattle; the feeding trials showed an increase in daily body weight of male Bali cattle by 0.6 $\mathrm{kg} / \mathrm{head} / \mathrm{day}$ and female Bali cattle by $0.52 \mathrm{~kg} / \mathrm{head} / \mathrm{day}$ compared to before giving concentrate which only had $0.2-0.3 \mathrm{~kg} / \mathrm{head} / \mathrm{day}$. The economic calculation shows that the production cost is $\mathrm{Rp} .2,950 / \mathrm{kg}$. The cost is still economical compared to the price of conventional concentrates on the market, with an average price of Rp.3,500-Rp.6,000/kg.

Training and field studies to the Sawit-Sapi Center to study concentrated feed processing technology and cattle maintenance management with the palm-oil plantation-cattle integration system expected to broaden horizons, increase knowledge, increase confidence, and motivate members of the Karya Bersama farmers group to make the livestock sector a family business. This activity aims to downstream the results of research that has been carried out previously in the field of the palm-oil plantationcattle integration system on the Sawit-Sapi Center, especially in concentrate feed technology and manure processing. The other purpose is to increase the knowledge of the palm-oil plantation-cattle integration system. This activity will provide benefits of increasing the ability to cattle maintenance by the Karya Bersama farmers groups with the application of concentrate feed. The concentrate feed application will facilitate the farmer when the dry season arrives due to reduced availability of forage in the palm oil area. The expected results of this program are the impact of providing concentrates for their cattle productivity. So the farmers are willing to use concentrate feed to increase productivity and are more motivated to make livestock as a family business, not just savings 


\section{METHODS}

\subsection{Activities period and location}

The community service activity conducted in 5 months, from July to November 2017. The community service activity carried out at the Sawit-Sapi Center, located in the Sei Rokan plant unit, Pagaran Tapah Village, Pagaran Tapah Darussalam Sub-District, Rokan Hulu District, Riau and in the Karya Bersama Farmers Group which included in the Maju Barokah Breeding Center, located in Karya Mulya Village, Rambah Samo SubDistrict, Rokan Hulu District, Riau Province. The distance between the two locations is approximately 30 KM.

\subsection{Socialization and training for concentrate feed production}

Activities are carried out through Field Studies at Sawit-Sapi Center UGM-PTPN V; the activity began with the explanation of concentrated feed technology for cattle. Exposure to the benefits and methods of feeding concentrated feeds is expected to give farmers an image regarding the concentrate feed. Then it continued with the introduction of the "Gama NR5" concentrate feed produced by UGM and PTPN V research development in the Sawit-Sapi Center to the farmers. Then it has proceeded with the presentation of the ingredients of the concentrate ration preparation, each function of feed ingredients of the "Gama NR5" concentrate feed and their uses or benefits for livestock. The demonstration of the process of producing "Gama NR5" concentrate feed from the preparation to the packaging stage. The farmer group members will see directly from the preparation process, grinding of feed ingredients, mixing, and packaging. This activity is expected to be able to give an idea to farmers about how to produce the concentrate feed. According to Ngadiyono et al. (2019), continuous assistance activities in groups of beef cattle can have an impact on the willingness of farmers to learn, gain understanding and knowledge about beef cattle culture management, able to make feed and processing livestock waste into compost independently. So that livestock productivity can be increased and optimal.

\subsection{Application trial of concentrate feed}

The activity was continued with the practice of giving concentrate feed to Bali cattle owned by farmers group members who were deliberately fattened. The practice of giving is accompanied by mentoring by team members in the Karya Bersama farmers group for two months. It is expected that after the trial assistance, farmers can be independent. The trial's technical implementation is to housing cattle that are usually released to graze on oil palm plantations. Each cattle will be given a concentrate feed of $2 \mathrm{~kg} / \mathrm{day}$. Assistance activities carried out for monitoring the cattle related to the acceptability of the concentrate. The acceptability refers to the level of palatability (preference) and the amount of consumption. With this assistance, farmers will find out the impact and benefits of using concentrate feed, which will improve the motivation of members of farmers groups to conduct enterprise in fattening cattle using concentrate feed.

\subsection{Activities evaluation}

After the activity completed, an evaluation phase carried out to collect information on the achievement of the target activities. The evaluation carried out is the response and participation of target farmers and the evaluation of feed that has been applied by the team and target farmers. According to Atmoko (2019), indicators of the achievements of community service through extension activity and assistance to smallholder farmers are active participation, willingness to follow the stages of the activity, and the nature of mutual assistance is realized during the activity takes place.

\section{RESULT AND DISCUSSION}

\subsection{Socialization with farmers group administration}

Initial socialization activities between the research team and the farmers' group administrators of the partner have carried out. This socialization includes the introduction of material and methods that will be carried out in the service activities. The introduction and explanation of the material needed by the farmer to be delivered is the main target in the initial socialization with the farmers' group administrator. Initial socialization activities produce topics needed by livestock to be conveyed and assisted during the service program. Some topics include:

1. feedstuff materials and preparation of concentrate feed ration,

2. the use of cattle manure as organic fertilizer for agriculture-plantation land,

3. introduction of diseases in Bali cattle, prevention, and treatment.

After the socialization activities, the preparation of counseling and mentoring materials was carried out for a predetermined and mutually agreed time. Interview data collection based on questionnaires conducted to obtain information related to the background of farmers breeders and cattle maintenance management carried out. The module guideline for cattle farming integrated with oil palm plantations was used as a tool for this activity, which shared with farmers.

\subsection{Concentrate feed production}

Concentrate feed production carried out using raw material for Palm kernel cake (BIS) at Sawit-Sapi 
Center feed mill. The integrated cattle maintenance system with oil palm plantations makes this feedstuff material abundant in the market at a more affordable price with high quality. The production carried out at the Sawit-Sapi Center due to the presence of a concentrate feed facility (feed mill) that often used for production.

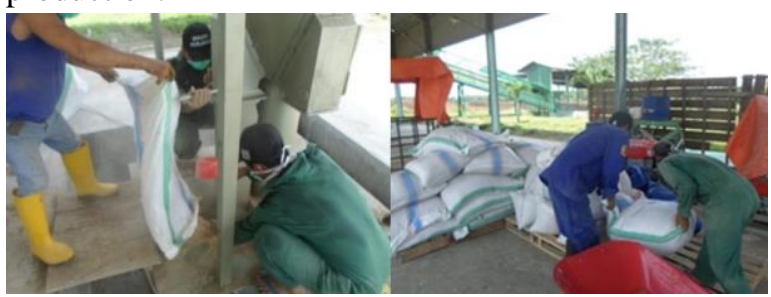

Figure 1. Gama NR5 Concentrate feed production at Sawit-Sapi Center feed mill
Gama NR5 concentrate feed production activities (Figure 1) at the beginning carried out as a preparatory step to carry out feed exploration activities to fatten for male cattle owned by farmers group. Concentrate feed that has produced is stored in a warehouse and packed in $50 \mathrm{~kg}$. The process of Gama NR5 concentrate feeds production shown in Figure 1. The feedstuff material and formulation of the concentrate feed based on Palm Kernel Cake (oil-palm plantation by-product) has registered with the patent number P00201907458 (Baliarti et al., 2019). The feedstuff used, proportions, and nutrient content of Gama NR5 concentrate feed are presented in Table1.

Table 1. The formulation of Gama NR5 concentrate feed in this activity

\begin{tabular}{|c|c|c|c|c|c|c|}
\hline \multirow[t]{2}{*}{ Feedstuff } & \multicolumn{2}{|c|}{ Nutrient content $(\%)$} & \multicolumn{3}{|c|}{$\begin{array}{l}\text { Nutrient content on feed } \\
\text { formulation }(\%)^{*}\end{array}$} & \multirow[t]{2}{*}{ Dry matter content $(\%)$} \\
\hline & $\mathbf{C P}$ & TDN & $\mathbf{C P}$ & TDN & DM & \\
\hline Palm kernel oil & 16.0 & 70.0 & 8.2 & 35.7 & 86.0 & $64-69$ \\
\hline Grind corn & 10.3 & 80.0 & 0.9 & 7.2 & 86.0 & 10.4 \\
\hline Rice bran & 8.0 & 67.8 & 1.9 & 16.4 & 86.0 & $31.14-37.21$ \\
\hline Molasses & 3.8 & 41.0 & 0.1 & 1.2 & 85.0 & 2.4 \\
\hline Urea & 281.0 & 0.0 & 2.3 & 0.0 & 100.0 & 0.8 \\
\hline Mineral & 0.0 & 0.0 & 0.0 & 0.0 & 100.0 & 1.0 \\
\hline
\end{tabular}

*: Nutrient calculation is based on proximate analysis of feedstuff mat and Indonesian feed ingredients table CP: crude protein; TDN: total digestible nutrients; DM: dry matter

\subsection{Application trial of concentrate feed at Sawit- Sapi Center}

Concentrate feed has produced continues after tested both their quality (proximate analysis method of Tilley and Terry) and palatability. Massive concentrate feed testing carried out in the Sawit-Sapi Center for pregnant cows and after calving for their calf. Concentrate feeding for pregnant cows presented in Figure 2.

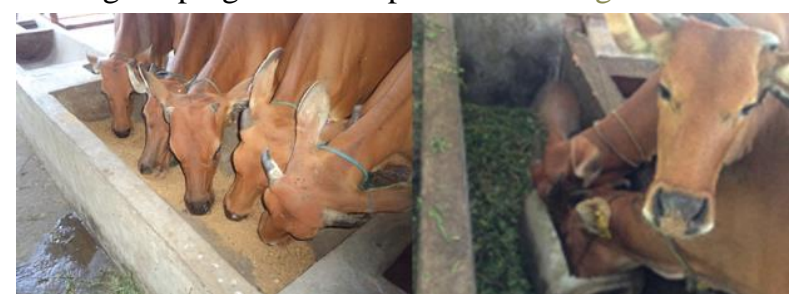

Figure 2. Application trial of concentrate feed at Sawit-Sapi Center and farmers group

Concentrate trial results on the female Bali cattle and their calf indicate a good level of palatability (acceptance), to maximize the production of all cattle because there is no wasted feed. Feeding concentrate on the Bali cows can shorten the calving interval, even $35.7 \%$ of the whole cow can reproduce less than one year. The concentrate can fulfill the nutrient deficiency of the weight body of cows, which increases during pregnancy and lactation. The body weight of cows can be ready to get pregnant again quickly. The calves fed by concentrate feed can provide additional daily body weight up to $0.55 \mathrm{~kg}$, which is higher than by forage under an oil palm plantation of $0.21 \mathrm{~kg}$.

Concentrate feed testing on Bali cattle productivity, reproduction and daily body weight gain, showed positive results so that its application in the farmers' group expected to have a good impact. As a comparison of $2 \mathrm{~kg}$ concentrated feed trials on fattened Aceh cows have been carried out and increased productivity compared to not being given concentrate feed (feed by forage/grass only). The increase in productivity includes the level of feed consumption (4.65 vs. $5.27 \mathrm{~kg} / \mathrm{head} /$ day), feed efficiency (4.52 vs. $13.42)$ and growth (0.17 vs. $0.72 \mathrm{~kg} / \mathrm{head} / \mathrm{day})$ (Budisatria et al., 2019)

\subsection{Distribution of concentrate feed to farmers group}

The distribution of concentrate feed from the SawitSapi Center feed mill to the Karya Bersama farmers group is carried out using a pickup truck. Concentrate feed distributed is 1 ton. Concentrate feed is stored in the farmers' group's feed warehouse for later 
distribution by group administrators to the farmers' group members. Distribution of concentrate feed accompanied by socialization and discussion. The method and the amount of feeding to each cattle that targeted for community service activities are explained to the farmers, so there is no error in its application. The socialization regarding the ingredients of concentrate feed and the effect on livestock was also conveyed to increase the knowledge and motivation of farmers for the use of concentrate feed.

The establishment of the Karya Bersama farmers group as a livestock feed barn by the Rokan Hulu District Plantation and Animal Husbandry Agency allows the group to process and run its concentrate feed industry. The government, through the service agency, has given some concentrated ingredients such as palm kernel cake, rice bran, and molasses. The limited knowledge and level of farmers awareness about the benefits of concentrate feed cause the enterprise to produce concentrate by farmers groups do not run well. Concentrate feed ingredients that are owned by farmers group are still stored in the warehouse. Storage of feed ingredients that have been too long can cause a decrease in quality due to lice attacks and organic reactions.

The activity of checking the concentrate feed ingredients owned by the farmers' group carried out to see the quality changes. Palm kernel cake is still well stored but has a large particle size mixed with palm kernel shells. Palm kernel cake should be broken down to be smaller size before being given to cattle. Cattle prefer the smaller size kernel. The condition of the rice bran has decreased in terms of texture, color, and aroma. Rice husk mixture is also commonly found in rice bran. Rice husk will have a negative effect on the level of livestock acceptance. The handling of rice bran ingredients is recommended by mixing other feed ingredients. Making TMR (Total Mix Ration) together with the palm midribs' grinder result is highly recommended. Total Mix Ration will help farmers when entering the dry season or the fasting month; farmers' activity in finding grass can be reduced. Molasses are still stored very well, so they can still be used without the need for handling first.

Checking the concentrate feed ingredients belonging to the farmers' group is carried out to see the occurrence of a decline in quality. Active discussion during the activity period is expected to educate the farmers group about storing concentrated feed ingredients and handlers that have been damaged to continue to be used as livestock feed. The application of appropriate technology for the manufacture of concentrate feed helps livestock groups to maximize available resources. Increasing farmers' knowledge and awareness of the quality of concentrate feed is also the aim of this activity.

\subsection{Socialization of cattle management in an integrated system with oil-palm plantation}

Integrated cattle raising with oil-palm plantations and rice farming will cut production costs for cattle, palm oil, and rice. The highest production cost for raising cattle is feed, reaching $70 \%$ of the total cost. Utilization of forage under oil palm plantation and fronds waste, as well as the by-products of rice farming as concentrate feed, will reduce the feed cost. Livestock waste in the form of manure can be used as fertilizer for plantations and farming, so the cost of using a fertilizer can be reduced. This maintenance system is more appropriate to be applied by farmers of the Karya Bersama farmers group who are also small-scale oil palm farmers.

Active socialization and discussion activities carried out to provide new insights to the farmers' group regarding integrated cattle raising systems. Each group member has an oil palm plantation and rice fields, so the feed for cattle is still available. At night, cattle are kept in the backyard; the manure can be collected. During the day, they are bound in the plantations area to graze forage. Waste from rice milling, in the form of rice bran, is used by farmers as additional feed for their cows. Several group members have implemented an integrated maintenance system, but constraints of long estrous distances, disease outbreaks, and feed difficulties during the dry season are still often experienced. The farmers' group already has a good recording card, but it is still constrained in its recording, making it difficult to evaluate cattle reproduction. Assistance on how to fill in and understanding with farmers groups about the importance of recording card completeness is done to overcome the reproductive problems faced by farmers. Socialization activities regarding integrated maintenance systems are expected to provide new knowledge for farmers to overcome the maintenance constraints experienced by applying appropriate technology.

\subsection{Activities evaluation}

Evaluation of the activities carried out is to look at the participation of target farmers in following this series of activities from the initial stage to the final stage. During the activities carried out from the start of socialization, concentrate feed production, concentrate feed distribution, concentrate feed trial, and counseling related to cattle maintenance management received a positive response and active participation of farmers. The next indicator is the response of the cows to the concentrate feed that has been produced, and the feed has excellent palatability (preferably the cows), there is no concentrate leftover during the trial period.

Concentrate feed testing on a laboratory scale is carried out to determine the nutrient content and quality 
of the concentrate feed. Laboratory scale test results help in increasing the motivation of farmers to participate in using concentrate feed. The feed proximate analysis test was conducted at the Nutrition and Animal Feed Laboratory, Faculty of Animal Science, Universitas Gadjah Mada. Concentrate feed nutrient content data are as follows, dry matter (DM) of $90.18 \%$, nutrient content of feed in dry matter, among others, ash $8.32 \%$, crude protein (CP) $17.42 \%$, extract eter (EE) $7.33 \%$ and crude fiber (CF) $20.64 \%$.

The analysis results showed good dry matter (DM) and crude protein (CP) content. These two parameters become the reference for determining the concentrate feed quality. The standard of $\mathrm{CP}$ content in concentrated feed ingredients commonly sold on the market is only about $12 \%$, so it can be seen that the concentrate feed produced by the Sawit-Sapi Center (Gama NR5) has quality better than the concentrate feeds on the market. The results of this analysis become a reference for farmers groups to be motivated to use concentrated feed.

The use of concentrates in Karya Bersama farmers group cows will give more production efficiency, especially the aspect of feed. The farmers gave rice bran as a concentrate for their cows for Rp.2,500-3,000/kg. Rice bran only contains DM 31-37\% and CP 8\% (Table 1). Whereas Gama NR5 concentrate had better content (DM 90.18\% and CP 17.42\%) despite had a relatively higher price, Rp.2,950/kg. Providing cows with the same amount $(2 \mathrm{~kg} /$ day concentrate as usual farmers provide), Gama NR5 concentrate would provide better nutritional consumption benefits than just rice bran. In $2 \mathrm{~kg}$ of feed given, Gama RN5 concentrate would contain $1.80 \mathrm{~kg}$ DM, while rice bran only contains 0.74 $\mathrm{kg}$ DM. High DM content would be allowed cows to consume better nutrition. The use of the Gama NR5 concentrate creates better feed efficiency than the provision of rice bran that has been carried out by The Karya Bersama farmers group. The concentrate feed increased the DM, average daily gain, feed efficiency, and decreased feed cost per gain of Rp.14,894 for Aceh cattle, so the farmers of Aceh cattle benefit from feeding concentrate feed (Koesmara et al., 2019).

\section{CONCLUSION}

Concentrate feed produced at the Sawit-Sapi Center containing $55-60 \%$ of palm kernel oil as a palm-oil plantation by product and then distributed to farmers for application trial on cattle belonging to farmer group members. Concentrate feed has excellent based on nutrient content and palatability. The nutrient content showed good dry matter (DM) of $90.18 \%$, and crude protein $(\mathrm{CP})$ crude protein $(\mathrm{CP}) 17.42 \%$. Each cattle given a concentrate feed of $2 \mathrm{~kg} / \mathrm{day}$, there is no concentrate leftover during the trial period.
Socialization activities regarding integrated maintenance systems expected to provide new knowledge to the farmers to overcome the cattle maintenance constraints experienced in the palm oil plantation by applying feed technology. The community service activities received a very positive response from the farmers' group. The farmers have actively participated, willing to follow the activity stages, and the nature of mutual assistance is realized during the activity. The activity is socialization, concentrate feed production, concentrate feed distribution, concentrate feed trial, and counseling related to cattle maintenance management. Assistance needs to be done continuously so that the application of the concept of concentrate feed in the palm-oil plantation-cattle integration system can run well.

\section{ACKNOWLEDGMENT}

Thanks for the Directorate of Community Service (DPKM), Universitas Gadjah Mada, for funding this community service activity through Hibah Penerapan Teknologi Tepat Guna (TTG) scheme in 2017 with the contract no 1568/DIT.PM/2017. Thanks, too, for all of the farmer that follow this activity.

\section{REFERENSI}

Atmoko, B. A., Baliarti, E., \& Fitriyanto, N. A. (2019). IPTEK Bagi Masyarakat (IbM) Melalui Peningkatan Panen Pedet dan Produksi Kompos Berkualitas Pada Kelompok Ternak Sapi Potong. Jurnal Pengabdian Kepada Masyarakat (Indonesian Journal of Community Engagement), $\quad 5(1), \quad 72$. https://doi.org/10.22146/jpkm.33874

Baliarti, E., Agus, A., Budisatria, I. G. S., Suhartanto, B., Yuriadi, Panjono, Guntoro, B., Bintara, S., Suwignyo, B., Hariyadi, T., Santosa, B. M., Wahyuni, S., Ariyanti, F., Atmoko, B. A., \& Yuwono, G. T. (2015). Program Pengembangan Integrasi Sawit-Sapi dan Transfer Teknologi Tepat Guna di Kawasan PT. Perkebunan Nusantara $V$.

Baliarti, E., Budisatria, I. G. S., Panjono, Yuriyadi, Maulana, H., \& Atmoko, B. . (2019). Pakan Konsentrat Untuk Sapi Berbasis Bungkil Inti Sawit (Patent No. P00201907458).

Baliarti, E., Gustianto, R., Agus, A., Budisatria, I. G. S., Suhartanto, B., Yuriadi, panjono, Guntoro, B., Bintara, S., Suwignyo, B., Hariyadi, T., Ariyanti, F., Atmoko, B. A., \& Yuwono, G. T. (2016). Performan Induk Bunting Sapi Bali Selama Bunting yang dipelihara Peternak Mitra PT. Perkebunan Nusantara V Riau. Simposium Nasional Penelitian Dan Pengembangan Peternakan Tropik, 216-221.

Baliarti, E., Gustianto, R., Maulana, H., Atmoko, B. A., \& Ibrahim, A. (2017). Sistem Pemeliharaan Induk Sapi Potong di Tingkat Petani-Peternak 
Plasma Perkebunan Sawit PT. Perkebunan Nusantara V. Seminar Teknologi Dan Agribisnis Peternakan V: Teknologi Dan Agribisnis Peternakan Untuk Mendukung Ketahanan Pangan, November, 471.

Budisatria, I. G. ., Ibrahim, A., Baliarti, E., Widi, T., Vierman, Koesmara, H., \& Atmoko, B. . (2019). Performance of Aceh cattle fed by concentrate with different levels. IOP Conference Series: Earth and Environmental Science, 387, 1-4. https://doi.org/10.1088/17551315/387/1/012040

Direktorat Jenderal Perkebunan. (2015). Statistik Perkebunan Kelapa Sawit Indonesia tahun 2014-2016. Direktorat Jenderal Perkebunan. Kementerian Pertanian Republik Indonesia.

Gunawan, \& Talib, C. (2014). Potensi pengembangan bioindustri dalam sistem integrasi sapi sawit. Wartazoa, 24(2), 67-74.
Kementrian Pertanian. (2014). Peraturan Menteri Pertanian Republik Indonesia Nomor 105/Permentan/PD.300/8/2014.

Koesmara, H., Budisatria, I. G. S., Baliarti, E., Widi, T. S. M., Nurtini, S., Umami, N., Ibrahim, A., Atmoko, B. A., \& Vierman. (2019). Income over feed cost of Aceh cattle fattened with forage and concentrate in different levels. IOP Conference Series: Earth and Environmental Science. https://doi.org/10.1088/1755$1315 / 387 / 1 / 012101$

Ngadiyono, N., Budisatria, I. G. ., Baliarti, E., Panjono, Widi, T., Yulianto, M., \& Atmoko, B. . (2019). Integrated Cattle Faming Development and Assistance in the Kandang Kalimasido. Jurnal Pengabdian Dan Pemberdayaan Masyarakat, 3(2), 211-222.

Yatma, R. A. (2017). Manajemen Pemrintahan Daerah dalam Gaduhan Ternak di Kabupaten Rokan Hulu Tahun 2012-2016. Jom Fisip, 4(2), 1-15. 